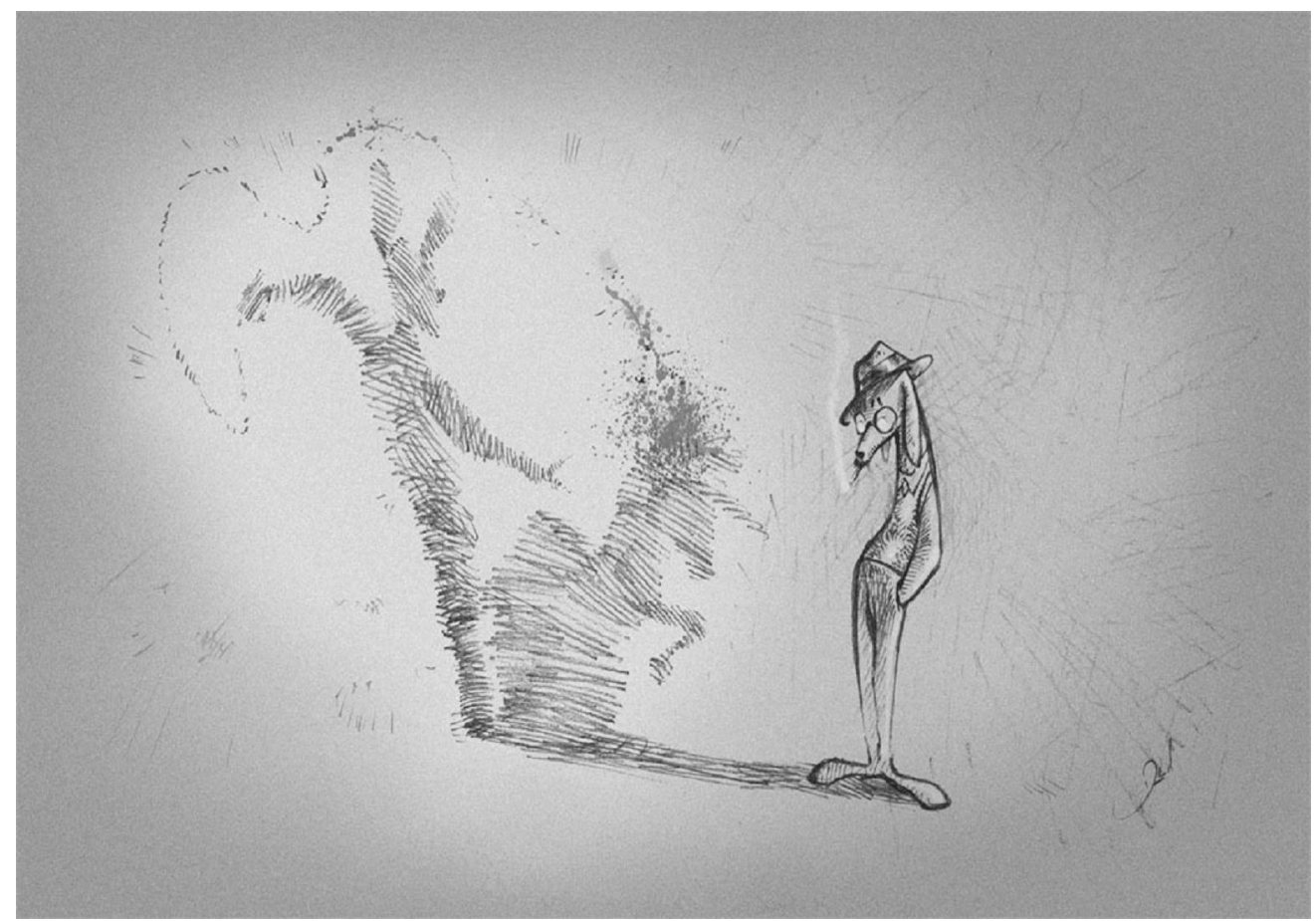

David Mussel

\title{
Estes animais em torno
}

\section{Affonso Romano de Sant'Anna}

Escritor brasileiro consagrado, foi cronista no Jornal do Brasil (1984-1988) e do jornal O Globo até 2005. Atualmente, escreve para os jornais Estado de Minas e Correio Brasiliense.

Ali, defronte à Pousada da Ponte, em Tiradentes, o menino abusava; chicoteava um cavalo,e eu já não agüentando mais, disse: - Olha aí, cara, você sabia que cavalo também é gente? ( $\mathrm{E}$ ele me olhando espantado, como se isso fosse uma revelação ameaçadora). É, ele é gente igual a você. Vê se trata dele melhor; ele não é seu? Pense que ele é seu irmão, ou você mesmo.

E fui pensando: para que chicotear o desvalido animal? Para que esporeá-lo, assim inutilmente, a não ser para exercer a força e o poder diante de um ser tangido obrigatoriamente à obediência? A rigor, não é de hoje que os animais me comovem. E salta na memória meu pai discutindo com um carroceiro, que chicoteava sadicamente um burro, diante de nossa casa, desnecessariamente. O olhar de pânico do animal, que não entendia nada do que estava acontecendo,e agitava o pescoço, tisnava as ferraduras nas pedras, erguia o corpo, se esfalfava por sair do lugar e daquela situação, desesperadamente. 
Meu pai deve ter dito ao carroceiro o que eu disse ao menino, ou melhor, eu disse ao menino em tiradentes o que meu pai disse ao carroceiro em Juiz de Fora, que burro é gente. Lembro-me que meu pai invocava a Sociedade Protetora dos Animais e foi a primeira vez que ouvi falar nisso. o carroceiro certamente não sabia o que era aquilo, ele que era um animal igualmente sem proteção de qualquer sindicato ou lei, com um sistema que também o chicoteava todos os dias, logo que a luz do sol lhe punha os arreios do trabalho.

O fato é que estou ficando cada vez mais sensível aos animais, e possivelmente a mim mesmo. Não bastassem os cães, preocupome até com a vida das formigas andando na pia e, se uma barata aparecer, colho-a dentro de um jornal e jogo pela janela; esmagá-la, jamais. Essa coisa de animais, plantas e até mesmo pedras, tudo tem vida. Há pouco li que um estudante de biologia, em Porto Alegre, se recusou a matar as cobaias, alegando que aquelas experiências podem ser feitas no computador e que ele estudava para ajudar e não para matar animais. Obteve uma liminar da justiça e levou para casa três lindas cobaias que iam ser sacrificadas.

Outro dia, no Egito, passei por sofrimento pior que aquele em Tiradentes. Dezenas de charretes conduziam centenas de turistas para a localidade em que estava o gigantesco "obelisco inacabado". Algumas charretes eram bonitas, bem tratadas, alguns burros também. Mas, quando começávamos a subir uma estrada e a besta se esforçando, suando para nos transportar, o dono da charrete começou a chicoteá-la. Cada chicotada batia era no meu lombo. Eu quase descendo para botar os arreios e ajudar o bicho a subir a ladeira. Ou quase pegando o carroceiro, botando os arreios nele, e fazendo-o puxar a charrete, agora comandada pelo burro. Não dá para defender os excluídos e miseráveis e continuar a maltratar a natureza e os animais.

Outro dia, estava em São João del-Rei, altas horas da noite, quando todos os bares e restaurantes se fechavam, passou por mim um cão, um cão vagamundo-vagabundo. Não sei por que lembrei-me de um verso de Paulo Mendes Campos em que recordava o tempo em que ele, como o cão metafísico, gania para a eternidade. Meu Deus! Cada vez estou mais próximo dos animais e de São Francisco! Olho o meu irmão cão, sinto uma dor canina atravessar-me os ossos no frio da noite mineira. Esse cão andarilho na noite deve ser eu mesmo. Ele é meu duplo, ou melhor, o meu uno.

Para onde está indo esse cão? Paro de prestar atenção na conversa de fim de noite na calçada. Eu o contemplo, enquanto ele olha algo longe, algo longínquo além daquela praça. Procura. Como que antenando algo, ele fareja o infinito. E, de 
Txt: Leituras Transdisciplinares de Telas e Textos, Belo Horizonte, v.5, n.9, p.84-86, 2009

repente, sai andando, como se soubesse para onde ir e o que buscar dentro da escura noite.

Que nem eu.

Julho de 2007. 